\title{
Local responses to the protection of medieval buildings and archaeology in British post-war town reconstruction: Southampton and Coventry
}

\author{
MARK S. WEBB \\ School of Archaeology and Ancient History, University of Leicester, LE1 7RH, UK
}

\begin{abstract}
Post-war planning and rebuilding of Britain's towns and cities led to rapid changes in medieval building stock, topography and character, as well as below-ground archaeology. Two case-studies of large, industrial, bomb-damaged yet important former medieval towns are examined in this article: Southampton and Coventry. Together, they illustrate the range of local responses to protecting what we now term the 'historic environment' in the period 1945 to 1955 at a time when a limited protection mechanism was introduced through the 1947 Town and Country Planning Act. The responsibility for compiling lists of protected buildings and providing resources to protect them largely fell to local solutions. Using previously unpublished archive material from both national and local sources, this article offers an alternative 'bottom-up', local, organized grass-roots viewpoint to most official 'top-down' accounts.
\end{abstract}

Most of Britain's larger towns ${ }^{1}$ have lost their former medieval character. In many cases, only isolated medieval municipal, religious or other 'monumental' buildings such as churches, walls and guildhalls remain amidst buildings and streets of a more recent era. Some are left as ruins as memorials or gardens, and other fragments exist in neglected corners, often without effective interpretation or context. ${ }^{2}$ Few of the medieval domestic 'vernacular' and mainly timber-framed buildings that surrounded these buildings survive, and in many cases medieval street patterns have been altered beyond recognition. The most important provincial late medieval towns such as Bristol, Norwich and Coventry have only small pockets of pre c. 1500 character remaining. While the City

${ }^{1}$ Large towns are referred to in this article as those with a current population of over 100,000. There are of course larger concentrations of medieval vernacular buildings in York and in smaller towns like Sandwich, Faversham and Lavenham.

2 C. Sandes, Archaeology, Conservation and the City: Post-Conflict Redevelopment in London, Berlin and Beirut, British Archaeological Review Report (Oxford, 2010), 5-6. 
of London retains a medieval street pattern and medieval street names, nearly all of its domestic medieval buildings were lost over 300 years ago. In addition, the results of below-ground medieval archaeological investigations are often inaccessible. Preservation in situ is by its nature difficult to manage in an urban environment and there are issues of public access where archaeological fragments are preserved beneath private modern buildings. The results of preservation 'by record' are often unavailable to the public in a readable form.

It is therefore difficult for contemporary communities in large British towns to understand the former medieval character and topography of the towns in which they live and work. Even experts have to work hard to piece together the remaining fragmentary evidence to obtain a coherent picture. The process by which this urban transformation happened is not fully understood either, except by a small number of experts or those who lived through the changes. There is often an assumption that the medieval character of British towns was changed by wartime bombing and post-war reconstruction and development. But Esher reminds us that this period was in fact a 'third wave' of change, following earlier rebuilds following the Great Fire of London and the re-facing and industrialization of British towns in the eighteenth and nineteenth centuries. ${ }^{3}$ Most British towns that were important in the medieval period had therefore lost much of their overall medieval character before the war.

Was it inevitable that individual or groups of damaged urban medieval buildings would be swept away and not rebuilt as facsimilies after the war? Would urban reconstruction and development take into account below-ground or previously hidden medieval archaeology and fragments of standing buildings, some of which had been exposed by wartime destruction? This study focuses on the decade after the war, when over 200 urban redevelopment plans were produced, most of them submitted to the Ministry of Town and Country Planning for approval. ${ }^{4}$ A study of decisions made about the role of medieval standing buildings and archaeology in urban reconstruction in the period 1945-55 is therefore of crucial importance in understanding the appearance of British towns and cities today.

Wartime destruction had focused attention on the need to decide what surviving medieval buildings to retain as never before. During the war, some of the decisions on which historic buildings should be saved were made at local level. Larkham and Nasr have recently demonstrated the wartime decision-making process made by the diocese of London regarding bomb-damaged churches in the City, some of them medieval. ${ }^{5}$

${ }^{3}$ L. Esher, A Broken Wave. The Rebuilding of England 1940-1980 (London, 1981).

4 P.J. Larkham and K.D. Lilley, 'Exhibiting the city: planning ideas and public involvement in wartime and early post-war Britain', Town Planning Review, 83 (2012), 647-68.

5 P.J. Larkham and J.L. Nasr, 'Decision making under duress: the treatment of churches in the City of London during and after World War II', Urban History, 39 (2012), 285-309. 
At national level, the process of creating the 'listing' structure of buildings of historical and architectural interest and how this emerged from wartime 'salvage lists', culminating in the 1947 Town and Country Planning Act, is described by Harvey and Saint. England was somewhat behind Scotland and Germany in creating such 'inventories'. ${ }^{6}$ Yet the protection mechanism established in 1947 was limited and relied heavily on local support. Not all local authorities felt that listed buildings should be accommodated in their reconstruction schemes and saving individual or groups of medieval buildings often fell to organized groups at a local level, including appeals to the public.

Rarely is much weight given to local opinion or 'heritage protection groups' regarding the loss of urban medieval fabric or to the role of individuals or groups concerned with its protection. Where criticisms to the plans are noted, the accounts refer to opposition from local traders or interference from the government. Accounts of post-war town reconstruction and development tend to give a top-down planning perspective and suggest a consensus for wholesale change. ${ }^{7}$ Many accounts were written by the town planners themselves. The published plans and public exhibitions were often a form of civic propaganda, sometimes allied to national morale-building. ${ }^{8}$

The conventional argument that there was a consensus on postwar urban development has now been challenged. ${ }^{9}$ But evidence for an alternative/'bottom-up' view of post-war town planning and reconstruction is by its nature problematic, involving letters to the local press, and later oral history accounts. ${ }^{10}$ Stamp sees a conflict between the sentimental affection for surviving historic fabric, largely amateur and

${ }^{6} \mathrm{~J}$. Harvey, 'The origin of listed buildings', Transactions of the Ancient Monuments Society, 37 (1993), 1-94; J. Harvey, 'Listing as I knew it in 1949', Transactions of the Ancient Monuments Society, 38 (1998), 97-104; A. Saint, 'How listing happened', in M. Hunter (ed.), Preserving the Past: The Rise of Heritage in Modern Britain (Stroud, 1996), 115-33; M.A. Cooper, 'Gerard Brown and the preservation of Edinburgh's Old Town', Transactions of the Ancient Monuments Society, 58 (2014), 134-54.

7 P. Hall, Cities of Tomorrow: An Intellectual History of Urban Town Planning and Design in the Twentieth Century, 1st edn (Oxford, 1988); J. Hasegowa, Replanning the Blitzed City Centre (Oxford 1992); P. Scott, 'The evolution of Britain's urban built environment', in M. Daunton (ed.), Cambridge Urban History of Britain, vol. III (Cambridge, 2001), 495-524; J. Pendlebury, Conservation in the Age of Consensus (Abingdon, 2009); A. Beach and N. Tiratsoo, 'The planners and the public', in Daunton (ed.), The Cambridge Urban History of Britain, 525-50; cf. G. Stamp, Britain's Lost Cities: A Chronicle of Architectural Destruction (London, 2007).

8 P.J. Larkham and K.D. Lilley, 'Plans, planners and city images: place promotion and civic boosterism in British reconstruction planning', Urban History, 30 (2003), 183-205; P.J. Larkham, 'Selling the future city. Images in UK post-war reconstruction plans', in I. Boyd White (ed.), Man-Made Future: Planning, Education and Design in Mid-Twentieth Century Britain (Routledge, 2007), 99-120.

${ }^{9}$ S.S. Cowan, 'The people's peace: the myth of wartime unity and public consent for town planning', in M. Clapson and P.J. Larkham (eds.), The Blitz and its Legacy: Wartime Destruction to Post-War Reconstruction (Farnham, 2003), 73-85.

10 P.L. Hubbard, L. Faire and K. Lilley, 'Contesting the modern city: reconstruction and everyday life in post-war Coventry', Planning Perspectives, 18 (2003), 377-97; K.D. Lilley, 'Conceptions and perceptions of urban futures in early post-war Britain: some everyday 
'vernacular' in focus, versus a professional body of architects and planners with a self-interested desire for change. The biggest issue was the pace of change rather than an attempt to turn back the clock altogether. Those opposing rapid change were often characterized as having a 'Colonel Blimp' mentality. ${ }^{11}$ This period also saw the growth in the number of civic societies, which tended to include heritage protection within a broader concern for civic improvement but the umbrella organization, Civic Voice, was not formed until 1957. ${ }^{12}$

Any account of preservation in this period must take into account the state of knowledge of medieval archaeology and standing buildings as well as conservation values of the time. Sandes takes the post-war rebuilding of three war-damaged cities (London, Berlin and Beirut) and examines the changing philosophies on conservation and evolving values with regard to below- and above-ground archaeology. ${ }^{13}$ In 1945, few individuals or local groups acting to help preserve medieval character in large British towns would have described themselves as 'conservationists'. Indeed, the concept of the 'historic environment' had not yet developed. Often, they were social historians who worked alongside local archaeological and historical groups who helped set an urban research agenda. ${ }^{14}$

Evidence for the activities of those concerned with the preservation of urban medieval buildings and archaeology, 1945-55, can be found in the under-utilized records of national amenity societies such as the Council for British Archaeology (CBA) and the Society for the Protection of Ancient Buildings (SPAB), supplemented by local municipal records and records of local and regional historical and archaeological groups. These sources reveal deep concerns about the changing nature of British towns and cities but also a lack of consensus even within the groups themselves.

The National Buildings Record (NBR), set up in 1941 to build on the emerging wartime 'salvage lists', effectively rejected the opportunity to have large numbers of timber-framed buildings statutorily protected in the 1947 Act. This was following a debate between traditionalist 'antiquarians' like NBR Director Walter Godfrey (1886-1961) and postmedieval architectural historians led by John Summerson (1904-92). The latter won the day, partly because the process of compiling a comprehensive list of buildings, including medieval vernacular buildings, at Grades I to IV would have unacceptably delayed the production of

experiences of the rebuilding of Coventry 1944-62', in Boyd White (ed.), Man-Made Future, $146-56$.

${ }^{11}$ G. Stamp, 'The art of keeping one jump ahead: conservation societies in the twentieth century', in Hunter (ed.) Preserving the Past, 77-99; D. Matless, Landscape and Englishness (London 1998), 193-6.

12 L.E. Hewitt, A Brief History of the Civic Movement (Liverpool, 2014).

13 Sandes, Archaeology, Conservation and the City.

${ }^{14}$ C. Gerrard, Medieval Archaeology: Understanding Traditions and Contemporary Approaches (London, 2003), 125. 
local authority reconstruction plans. Summerson felt that that it was unrealistic to protect all medieval buildings and so it would be better to focus on the best examples, where possible. He doubted whether towns even had a medieval 'character' that was definable or capable of being saved. ${ }^{15}$ Instead, vernacular medieval buildings usually only made the 'supplementary' non-statutory list at Grades III and IV, whose fate was to be left to the discretion of local authorities. The only stipulation was that they should be recorded if a local authority felt that there was no alternative but demolition. But in effect, few detailed records were ever made. Several medieval buildings were removed immediately, for example a group of medieval merchants houses in Exeter, despite a public enquiry and a number of sixteenth-century buildings in Norwich. ${ }^{16}$

The post-war emphasis on preserving individual buildings of particular merit, rather than groups that included 'lesser' examples, had a big impact on remaining pockets of medieval character and often destroyed the townscape context of the more highly rated buildings that were allowed to survive. Large numbers of medieval domestic buildings had already been destroyed in slum clearances in the half century prior to the war. Their 'picturesque' quality was not deemed to be enough to save them, despite published works by A.R. Powys, secretary of the SPAB (1929) and Godfrey (1944), which outlined how these buildings could be converted to have a useful life. ${ }^{17}$ Often, a building's importance was only recognized during the process of demolition. Many of them remained hidden behind later stucco or brick façades and did not appear to be medieval at all unless examined internally. The expertise to recognize the importance of these buildings did not exist beyond a small number of specialists. The Vernacular Architecture Group was not formed until 1954 and an 'archaeological' approach to vernacular buildings did not emerge until the 1960s. ${ }^{18}$ The age and therefore importance of some buildings was often badly underestimated by applying the dating techniques of the time, which relied on recognizing architectural features and roofing construction. Dendrochronology techniques were not commonly used on vernacular housing until the 1980s.

Nor was there a good deal of detailed study of below-ground urban medieval archaeology by 1945. Post-war archaeology still had a Roman or

15 Saint, 'How listing happened', 123; S. Croad, 'The national buildings record: the early years', Ancient Monument Society, 36 (1992), 79-98; P.J. Larkham, Continual Change: A Century of Conservation in England, Birmingham City University, Centre for Environment and Society Research Working Paper Series, 21 (Birmingham, 2013); J. Summerson, 'The past in the future', in J. Summerson (ed.), Heavenly Mansions and Other Essays on Architecture (London, 1949), 219-42, at 231-2.

16 A. Fox, Aileen: A Pioneering Archaeologist (Leominster, 2000), 120-1; B. Ayers, Norwich: Archaeology of a Fine City (Amberley, 2009), 171-82.

17 Pendlebury, Conservation in the Age of Consensus, 24; W.H. Godfrey, Our Building Inheritance (London, 1944), 45-6.

18 W.A. Pantin, 'Medieval house plans', Medieval Archaeology, 6-7 (1962-63), 202-29; M. Wood, English Medieval Houses (London, 1965). 
prehistoric focus and was largely practised outside towns by universities, museums or amateur groups. Until then, urban medieval excavations had been largely restricted to monumental structures such as religious buildings, castles and town walls. Few felt that medieval archaeology could contribute anything about urban development that was not already known from municipal documentary archives. ${ }^{19}$ The CBA was set up in 1943 to promote archaeological investigation in British towns, in response to anticipated large-scale redevelopment, and encouraged the establishment of special units. It included representatives from local as well as national groups. ${ }^{20}$ Even then, a medieval research focus to archaeology in British towns did not really emerge until the 1960s. Only in excavations in London between 1947 and 1968 under Professor Grimes and in Canterbury from 1944 under Audrey Williams was there a research agenda that included the medieval period. ${ }^{21}$ Elsewhere, medieval layers were cut through rapidly in an attempt to reach Roman layers. A medieval focus to non-monumental urban archaeology took place much later, including Plymouth in 1959, Gloucester in 1968 and Leicester and Coventry in 1971. The CBA singled out 51 towns as having 'historic significance'. In only 12 of them were specific redevelopment plans put in place that respected medieval character, including narrow streets and groups of ordinary vernacular buildings. Some of these plans, such as that for Warwick, were put together by planners like Patrick Abercrombie (1879-1957), better known for taking a more radical approach in larger towns. $^{22}$

It is also necessary to consider the nature of the reconstruction plans in the period c. 1945-55. The government had given local authorities in bombdamaged towns sweeping powers to make compulsory purchase of large swathes of land in order to redevelop. But in effect, only Plymouth and the Barbican area of London were completely reordered. ${ }^{23}$ The ideas of Le Corbusier and Munford in which the old medieval streets of British towns were seen as a legacy of poor planning and not fit for the modern era were influential, but not universally followed. Around half of local authorities employed engineers, architects and surveyors rather than well-known town planning consultants. ${ }^{24}$ British post-war reconstruction had its own modernist character that often took account of medieval buildings, both in terms of preserving the 'best' examples in an 'improved setting' and in designing new buildings that had a 'nod' to the past. Coventry's shopping

${ }^{19}$ H. Clarke, The Archaeology of Medieval England (Oxford, 1984), 177-8; M. Biddle and D.M. Hudson, The Future of London's Past: A Survey of the Archaeological Implications of Planning and Development in the Nation's Capital, Rescue Publications, 4 (Worcester, 1973), 98.

20 Gerrard, Medieval Archaeology, 125.

21 J. Shepherd, The Discovery of the Roman Fort at Cripplegate, City of London, Excavations by W.F. Grimes, 1847-1968 (London, 2012).

22 J. Pendlebury, 'Planning the historic city: reconstruction plans in the United Kingdom in the 1940s', Town Planning Review, 74 (2003), 371-93.

23 J. Gould, Plymouth: Vision of a Modern City (Swindon, 2010).

24 Larkham and Lilley, 'Exhibiting the city'. 
precinct and realignment of the Broadgate area were seen as radical. Donald Gibson, Coventry's architect-planner, 1938-55, had a vision for low-rise buildings and pedestrianized streets that framed the surviving medieval tower and spire of St Michael's cathedral. His approach was more influenced by the Beaux-Arts tradition and the more moderate modernism of Abercrombie than a conventional Corbusian approach. ${ }^{25}$ Efforts were made, albeit with mixed results, to establish a unified civic sense amongst so much that was new, often through the use of medieval heraldry and public art. ${ }^{26}$ Interestingly, few suggested that archaeology could be an effective tool in creating a sense of place in the redeveloped town.

Popular enthusiasm for town planning reached its peak during the period of the worst of the bombing, c. 1940-41 but thereafter plummeted as people hankered for normalcy, and to the disappointment of local authorities $^{27}$ who had seen the central planning of towns as a way to resolve economic and social problems, assisted by the compulsory purchase powers given to them by the government in 1944. But nearly all post-war town plans were altered several times and resulted in compromises, due to the difficult post-war economic circumstances and shortage of building materials. The extent to which medieval buildings, archaeology and character would be retained in these reconstruction plans depended on local rather than national decisions. Mostly, the work of compiling provisional lists of historic buildings worthy of protection was given to local history, archaeology and other amenity societies and with the local authority having the final say before submitting their town's list to the Ministry of Town and Country Planning for approval. Nor did the 1947 Act provide resources to 'police' the lists once agreed, and the Ministry admitted that it was largely up to local societies to protect threatened buildings by appeals to the public. ${ }^{28}$

No studies have examined the impact of immediate post-war redevelopment and the new protective structure under the 1947 Act on specifically medieval urban standing buildings and archaeology in great detail and at grass-roots level. Kelsall has examined the impact on Victorian buildings, relatively few of which were included in the 1947 Act lists. ${ }^{29}$ Mindful of

${ }^{25}$ L. Campbell 'Paper dream city/modern monument. Donald Gibson and Coventry', in Boyd White (ed.), Man-Made Future, 121-44.

${ }^{26}$ Ibid., 133-5; P.M. Hubbard, L. Faire and K. Lilley 'Memorials to modernity? Public art in the city of the future', Landscape Research, 28 (2004), 147-69.

${ }^{27}$ N. Tiratsoo, 'The reconstruction of blitzed British cities, 1945-55: myths and reality', Contemporary British History, 14 (2000), 27-44.

${ }^{28}$ C. Flinn, 'Reconstruction constraints: political and economic realities', in Clapson and Larkham (eds.), The Blitz and its Legacy, 87-97; Woodfield papers, 16 Apr. 1962, R. Ditchfield, Ministry of Housing and Local Government, to C. Woodfield, in reference to a Ministry visit in 1954, admitting that the system relies on local societies informing the public, C. Woodfield reply 3 Aug. 1962 saying that this is 'unrealistic' (Woodfield documents lent by a friend of the Woodfield family).

${ }^{29}$ F. Kelsall, 'Not as ugly as Stonehenge: architecture and history in the first lists of historic buildings', Architectural History, 52 (2009), 1-29. 
how local planning decisions had such a big impact on the survival of medieval character in large British towns and cities, this article examines the large bomb-damaged former medieval cities of Southampton and Coventry, using material previously unpublished from national and local archives.

\section{Coventry and Southampton in 1945 compared}

These towns have been chosen for detailed study because they faced typical dilemmas of other large post-war British cities with surviving historic fabric, but the outcomes were different. What place should historic buildings have in the future of urban reconstruction, balancing the urgent need to restore essential services, house the displaced and boost flagging rates revenues, yet retain optimism and morale for a better future? Could medieval archaeology and standing buildings be used to create a 'sense of place' in a fast-changing urban environment? Former medieval cities like bomb-damaged Bristol, Newcastle, Plymouth and Hull also faced these issues, as well as those like Leicester and Gloucester that had escaped wartime damage to their historic cores.

Both Coventry and Southampton had Saxon origins. Southampton grew as an important trading port, first with France in the twelfth and thirteenth centuries, and later with Italy and Spain in the fifteenth century. It was an entrepôt for merchants across southern England and the Midlands, and was an important part of the defensive network of the southern coast. But the disruption in international trade through war and the increasing dominance of the port of London and London merchants led to a decline in Southampton's importance from the mid-fifteenth century onwards. Coventry's early medieval development was slower, but after the midfourteenth century grew rapidly on the back of England's burgeoning wool and cloth trade. Its wealth and population size made it the fourth ranked English city after London, York and Bristol, before decline set in by c. $1500 .^{30}$

By the twentieth century, both cities had experienced the effects of rapid population growth. By 1939, both cities had populations of around $200,000 .{ }^{31}$ A third of the working population of Southampton was employed in the shipping industry. Coventry's growth was particularly rapid, based around the motor car and engineering industries in which 70 per cent of its working population was employed. Between 1931 and 1939, it had been the fastest-growing city in the country, with 42,000 migrants, attracted by the relatively high wages in the engineering industries. ${ }^{32}$

30 C. Platt, Medieval Southampton: The Port and Trading Community, AD 1000-1600 (London, 1973); C. Phythian-Adams, Desolation of a City: Coventry and the Urban Crisis of the Late Medieval Ages (Cambridge, 1979).

31 Southampton's 1939 population was 181,000 and Coventry's was 214,000.

32 K. Richardson, Twentieth-Century Coventry (Coventry, 1972), 277; N. Tiratsoo, Reconstruction, Affluence and Labour Politics: Coventry, 1945-1960 (London, 1990). 
Both cities had surviving groups of recognizably medieval buildings and a largely medieval street plan by 1939 although neither city could be described as 'medieval' in character. The intra-mural 'old town' of Southampton had been relatively protected from industrial development by the development of reclaimed land outside the medieval walls to the west and the development of municipal buildings to the north. But slum clearances in the north-west part of the intra-mural 'French Quarter' of the town in 1899-1903 and 1911 had destroyed large numbers of vernacular buildings and medieval streets including Simnel Street, Bugle Street and Blue Anchor Lane. ${ }^{33}$ Part of the northern medieval walls had been taken down to improve traffic flow, leaving fourteenth-century Bargate as an island. But otherwise, the medieval town retained pockets of medieval character, particularly stone-built structures and cellars, and a number of other fourteenth- and fifteenth-century houses hidden behind later façades. In 1950, when archaeologist O.G.S. Crawford completed his research into the character of the High Street, he concluded that the layout of the street and the streets leading off it was exactly as in the medieval period. $^{34}$

Timber-framed buildings were very much a visible presence in Coventry between the wars. Local historian Mary Dormer-Harris in 1908 noted that had some of the buildings in the town been better maintained, Coventry would have compared with medieval Nuremburg. ${ }^{35}$ Inter-war traffic schemes in the city centre had severely altered some of the last remaining pockets of medieval character in the central core. The most notable had been the elimination of the medieval Butcher Row and Ironmonger Row area in 1936 to create Trinity Street. Nevertheless, important buildings like St Michael's cathedral, Holy Trinity church, St Mary's Guildhall and others such as St John the Baptist church and Ford's and Bond's Hospitals remained, and several ordinary medieval vernacular buildings survived outside the historic core. ${ }^{36}$

Both cities could be fairly described as 'working-class' towns. Both had elected Labour governments in the local elections of November 1945. Local government in both towns had been working on reconstruction schemes prior to the war, with an examination of how town planning could bring social benefits through new housing and provision of municipal buildings as well as dealing with traffic problems. Neither city had a particularly strong tradition of local wealthy philanthropy or involvement in cultural activities. In Leicester, a 'Literary and Philosophical Society' had been formed in 1835 by wealthy commercialists and others living

${ }^{33}$ M. Doughty (ed.), Dilapidated Housing and Housing Policy in Southampton 1890-1914 (Southampton, 1986).

34 Southampton Record Office (SRO) (unreferenced), Crawford's Talk on the High Street Southampton, 1950.

35 M. Dormer Harris (ed.), A Selection from the Pencil Drawings of Nathanial Troughton (London, 1908), 52.

36 S. Jones, 'Timber-framed buildings in Coventry', report for Victoria County History (1958). 
in the city, helping set up the New Walk Museum and involving themselves in local urban developments by fighting to preserve particular medieval buildings. Their activities were complemented by an influential archaeological society, formed 20 years later. ${ }^{37}$ In neither Southampton nor Coventry did anything comparable exist. An archaeological society existed in Coventry from 1934, but it mainly comprised of a group of amateur enthusiasts who preferred to focus on Roman archaeology outside the city. It was left to amateur archaeologist J.B. Shelton (18751958) to salvage what he could amongst the inter-war development of central Coventry from 1924. ${ }^{38}$ William Spranger had saved 'Tudor House', the finest fifteenth- and sixteenth-century timber-framed house in Southampton, and opened it as a museum in 1912. ${ }^{39}$

In neither city was there a prolonged debate about reconstructing destroyed or severely damaged streets exactly as they had appeared before 1940. Even suggestions, backed by popular opinion, to reconstruct a replica of the destroyed St Michael's cathedral, Coventry, came to nothing. ${ }^{40}$ The recently restored fifteenth-century Palace Yard, Earl Street, one of the finest medieval courtyard houses in the country, had taken a direct hit during the war. Sited in an area earmarked for the city council's civic centre and an open public space, its reconstruction was not even discussed by the city council. Smithford Street, one of the main thoroughfares of the medieval city, had been severely damaged but instead of being restored, it was unrecognizably buried beneath Gibson's new shopping precinct. Southampton's medieval buildings fared better and in High Street many remains of stone-built houses and undercrofts from the town's medieval trading heyday had survived. ${ }^{41}$ Wartime bombing had also revealed evidence of numerous fifteenth-century tenement plots and are shown amongst the 5,000 photographs of the bomb-damaged town taken by Crawford. ${ }^{42}$

\section{Southampton}

In the early stages of the war, the local authority was interested in a bold solution to post-war reconstruction. In 1942, a plan was put forward by the city engineer $\mathrm{H}$. Cook together with the renowned town planning consultant Stanley Adshead (1868-1946). This would have developed the area immediately north of Bargate and the medieval walls, creating a new

37 J. Simmonds, Leicester Past and Present: Modern City 1800-1974, vol. II (London, 1974).

38 M. Rylatt and A.F. Adams, A Harvest of History: The Life and Work of J.B. Shelton MBE (Coventry, 1986).

39 Tudor House and Garden (Southampton, 2013).

${ }^{40}$ Richardson, Twentieth-Century Coventry, 168; L. Campbell, 'Towards a new cathedral: the competition for Coventry cathedral 1950-1', Architectural History, 35 (1992), 210.

41 G.L.O. Copeland to M. Dance, secretary SPAB, 2 Jun. 1949, SPAB archive Southampton.

42 Gerrard, Medieval Archaeology, 88; K. Hauser, Bloody Old Britain: O.G.S. Crawford and the Archaeology of Modern Life (London, 2008), 233. 
shopping focus around a 'circus'. But the plan was opposed by traders in High Street, and even the government, on safety grounds. The main reason for abandoning the plan, however, was that it was unaffordable. Town planning solutions were not popular with the local public either. A meeting of the Civic Society to discuss Southampton's future in 1942 was attended by only 100 people. $^{43}$

In the end, any controversy over Southampton's final 'Wooldridge Plan' was largely restricted to the extent of land the local authority would be allowed to purchase, and to a proposed north-south road (later known as 'Castle Way') to the port. The latter would have cut straight through the remaining medieval section of the 'old town', through the town walls and the site of the castle bailey and uncomfortably close to St Michael's church. It also threatened medieval Bernard Street, French Street and Brewhouse Lane. This threat to some of the last remaining areas of medieval character in the city was recognized by the regional committee of the Ministry of Town Planning who opposed it. ${ }^{44}$

Hasegowa believes that bold town planning schemes for Southampton were defeated by a combination of vested interests, a timid local authority and government interference but he underplays the role of a newly formed body, the Friends of Old Southampton Society (FOSS). ${ }^{45}$ Anticipating the development of the town that would follow the war, the FOSS was set up in 1946 by O.G.S. Crawford (1886-1957), who was noted for his contribution to the field of urban, landscape and aerial archaeology and also for founding the respected journal Antiquity in 1927. Crawford had also been archaeological officer at the Ordnance Survey in their Southampton office between 1920 and 1940 and had then worked for the NBR until his retirement in $1945 .{ }^{46}$ The aim of the FOSS was to 'foster interest in [Southampton's] antiquities and do all possible to preserve them' ${ }^{47}$ The FOSS acted as a self-proclaimed 'watchdog' of the town's historic buildings and archaeology, of which the medieval remains were the most significant. From the outset, Crawford, director to 1955, insisted that the FOSS should be independent of the local authority and the Southampton Civic Society, despite the latter's requests that the two organizations join forces. The Civic Society had not specifically included heritage protection among its objectives in its revised constitution in 1942, preferring to focus on a new civic centre, architectural design, housing, industry and a new airport. ${ }^{48}$ Although it took an interest in the town's history and

43 A.B. Rance, Southampton: An Illustrated History (Southampton, 1986), 173; Hasegowa, Replanning the Blitzed City, 50-4.

44 Southern Daily Echo, 1 Jan. 1952.

45 Hasegowa, Replanning the Blitzed City, 100-6, 110-12.

${ }^{46}$ SRO, 26 Aug. 1946, inaugural meeting invitation letter; FOSS Constitution, S/S 10/1/1; O.G.S. Crawford, Said and Done: The Autobiography of an Archaeologist (London, 1955).

47 Southampton Echo, 29 Aug. 1946; Friends of Old Southampton Constitution, FOSS papers 1946-62, SRO, D/S 10/1/1.

${ }^{48}$ Southampton Civic Society Constitution, SRO, D/S 10/1/7. 
had commissioned surveys into historic buildings, the Civic Society had actually proposed the new north-south road.

The FOSS committee of 11 members comprised what might be termed representatives of the intellectual and cultural elite of the town, including the curator of Tudor House Museum, the vicar of St Michael's church, lecturers from the local university departments of geography and history and the head of the local education unit. But from the start, the FOSS was set on outreach to and education of the general public rather than the somewhat narrow academic approach followed by historical societies in some other towns. Crucially, a key member of the FOSS committee was the editor of the Southern Evening Echo. The latter referred to the FOSS as 'a strong body of enlightened opinion' which otherwise would not have an outlet for its voice. The FOSS held regular lectures and excursions (see Figure 1) and was adept at informing and educating the public through the local press. From an initial membership of 60 in 1946, it grew to over 200 by 1947 and still further into the 1960s. It also had a strong youth membership. The FOSS records and local newspaper reports reveal a large correspondence from citizens wanting to learn about Southampton's heritage, and how to get involved. The FOSS was also a pioneer in advocating full-scale archaeological excavation prior to redevelopment. In 1954, it set up an excavation sub-committee and there was an appeal for volunteers in the press with 'no experience necessary'. Even a youth archaeological unit was set up. Initial excavations were in Vyse Lane and Bargate Street in 1954 and were extended to include the former castle site the following year. ${ }^{49}$

By the time the FOSS had formed, Southampton's list of protected historic buildings had already been produced. The local authority already had a positive view of its medieval buildings, and well before the 1947 Act, it had commissioned reports and suggested that some archaeological areas might be preserved for public space. ${ }^{50}$ Of the 108 buildings proposed for listing in 1946-47 together with 28 scheduled ancient monuments, 88 of them fell under the comprehensive development area proposed in the 1952 and 1954 Southampton town plans. There was also a supplementary list of 42 buildings that did not merit listing but 'which should be given special regard' ${ }^{51}$ These included a number of medieval buildings such as the stone undercroft 'Lankasters Vault' (137-41 High Street), the Duke of Wellington pub and fourteenth-century 58 French Street (now known as 'Medieval Merchants House'). The bombed-out Holy Rood Church on High Street was also on the list but its surviving medieval walls were secured by public subscription as a memorial to the merchant navy. There was even a section on the town's topography and history provided by

49 FOSS papers 1946-62, SRO, D/S/1/63, e.g. Southampton Echo, 22 Jan. 1952.

50 Saint, 'How listing happened', 122; Gerrard, Medieval Archaeology, 88.

51 SRO, County Borough of Southampton Development Plan Central Area no. 3, 1953. 


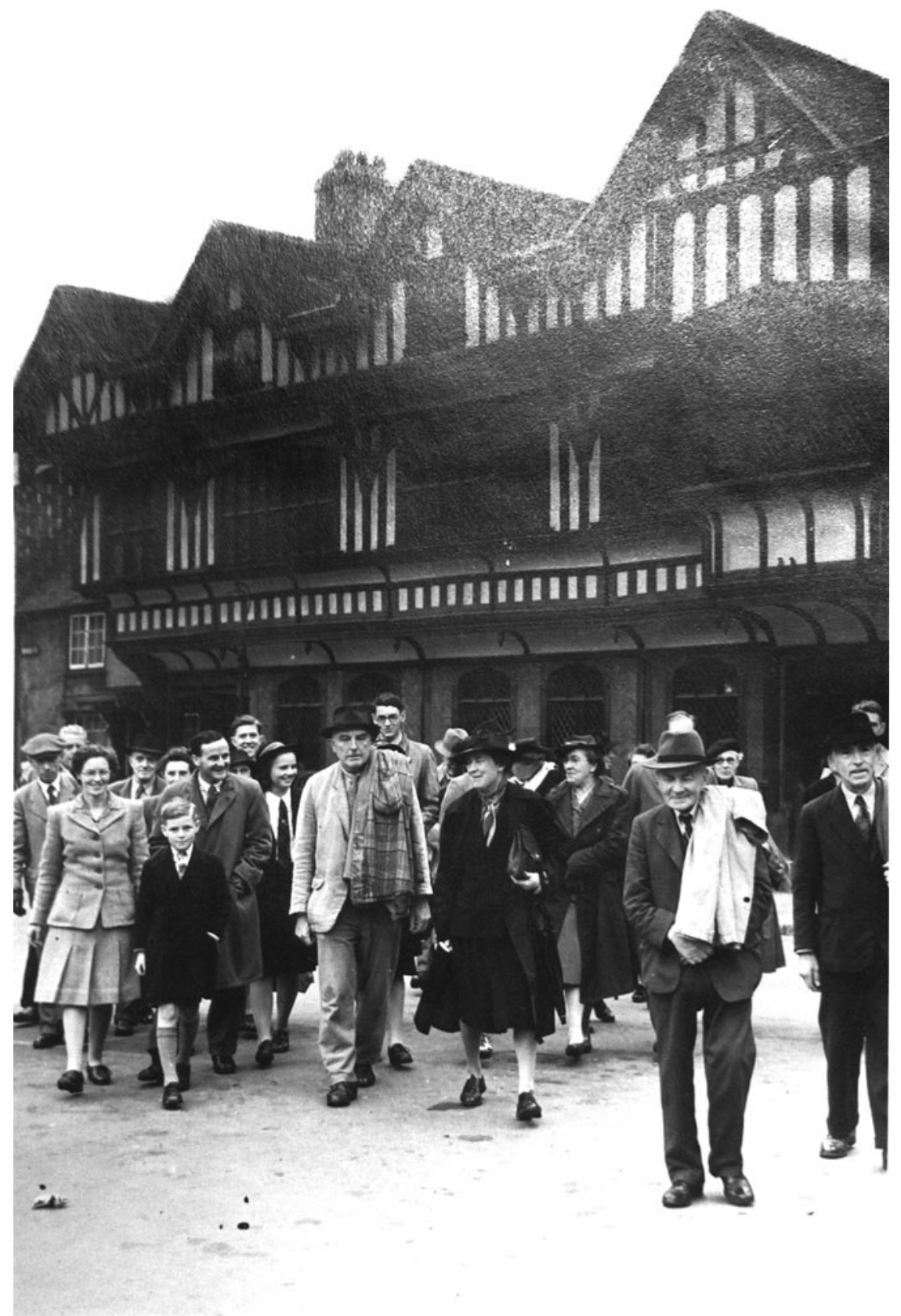

Figure 1: The Friends of Old Southampton Society outside Tudor House, with Crawford in the centre. Southern Daily Echo, 13 Sep. 1946. 
Crawford in the 1954 published plan. Surviving buildings were to be given an 'improved setting'. ${ }^{52}$

Yet threats remained to parts of the town wall, the Duke of Wellington pub, 58 French Street and 'Lankasters Vault' (see Figure 2). The FOSS kept up the pressure on the local authority during the public enquiries in 1955 and 1957, with Crawford in the lead. The local authority eventually adapted its road plan by turning the southern section of the road into a narrower, service road and locating it slightly further away from St Michael's church. The number of affected historic buildings was reduced from 13 to $6{ }^{53}$ Few other local authorities in this period were prepared to alter their plans to this extent to accommodate historic buildings and streets.

The relatively co-operative environment between the local authority and the FOSS was partly a reason why Southampton became one of the earliest and most extensively investigated medieval towns in the country. ${ }^{54}$ The council provided $£ 100$ towards the FOSS excavations in 1955 and took over the excavations two years later. The medieval excavations in Southampton were exceptional at a time when there was still an exclusively Roman focus to excavations in other towns. Standing buildings were also restored. The fifteenth-century God's House Hospital and Tower were provided with council funds and eventually became an archaeology museum. Other restorations included 58 French Street and the Guildhall Museum at Bargate. Crawford expressed appreciation of the council's efforts in his annual address to the FOSS on 14 July 1952, saying that the council had done a lot for the citizens in terms of reconditioning old buildings, and when in 1959 the Society for Medieval Archaeology held its second annual conference Southampton, the attendees were impressed by how well the town's medieval buildings were cared for. In Southampton, medieval archaeology and standing buildings were embraced within a post-war redevelopment plan and were considered important to fostering a 'sense of pace' in a fast-changing urban environment. ${ }^{55}$

\section{Coventry}

After the war, the 'martyr status' of the city, symbolized by the shell of the bombed-out medieval parish church (cathedral from 1918) of St Michael, emboldened the local authority to press ahead with its

52 SRO, County Borough of Southampton Development Plan Central Area no. 3, 1954.

53 FOSS papers 1946-62, SRO, D/S 10/1/7.

${ }^{54}$ C. Platt and R. Coleman-Smith, Excavations in Medieval Southampton (Leicester, 1975); T. Champion, 'Protecting the monuments: archaeological legislation from the 1882 Act to PPG16', in Hunter (ed.), Preserving the Past, 50-2.

55 FOSS, AGM minutes, FOSS papers 1946-62, SRO, D/S 10/2; D. Brown, 'Sense and sensitivity - or archaeology versus the "wow factor" in Southampton (England)', in J. Schofield and R. Szymanski (eds.), Local Heritage, Global Context: Cultural Perspectives on Sense of Place (Farnham, 2010), 157-71. 


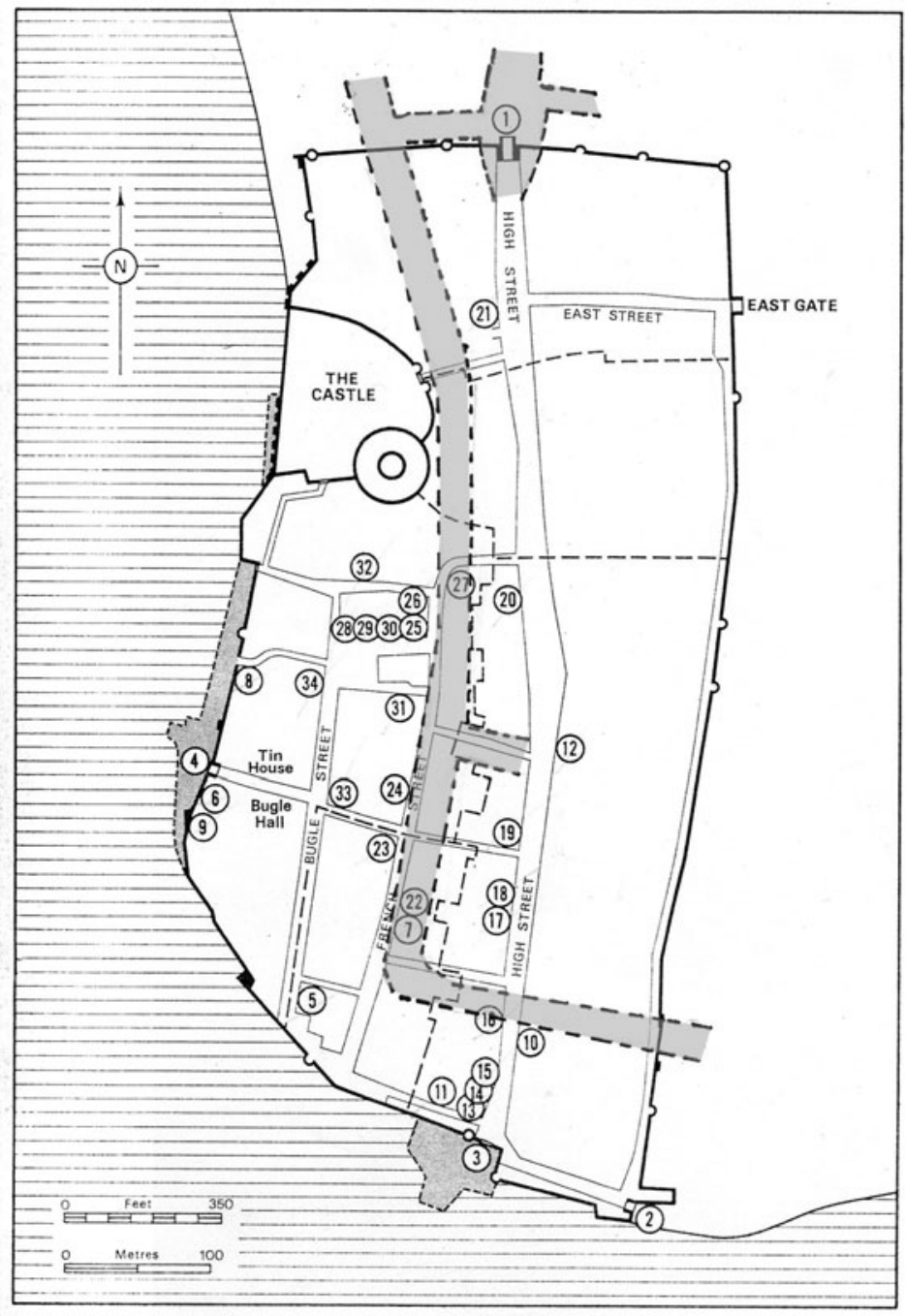

\begin{tabular}{|c|c|c|c|c|}
\hline 1 Bargate & 8 Blue Anchor Lane & 15 Quilter's Vault & 22 Weigh House Vault & 29 Church Hall \\
\hline 2 God's House Gate & 9 Cuckoo Lane & 1694 High Street & 2358 French Street & 30 n St Michae's Square \\
\hline 3 Water Gate & $1079 / 2$ High Street & 17104 High Street & 24 46-48 French Street & 31 Woollen Hall \\
\hline West Gate & 11 Porters Lane & 18106 High Street & 25 French Street/St Michael's Square & 32 The Undercroft \\
\hline Wool House & 12 Red Lion & 19111 High Street & 26 West Street/ Simnel Street & 33 Duke of Wellington \\
\hline 6 Tudor Merchant's Store & 13 Canete's Palace Vault & 20 Oueen's Hotei & 27 Corner of West Street & 34 Tudor House \\
\hline 7 Weigh House & 1488 High Street & $21169-170$ High Street & 2813 St Michaeits Square & \\
\hline
\end{tabular}

Figure 2: Proposed route of the proposed north-south road (Castle Way) through the centre of medieval Southampton. After P.A. Faulkner, 'The surviving medieval buildings', in C. Platt and Coleman-Smith, Excavations in Medieval Southampton (Leicester, 1975). 
pre-war town planning schemes, in spite of reservations expressed by the government about cost and lack of public consultation. ${ }^{56}$ In Coventry, the local authority was more successful than most at deflecting government criticism, by claiming to have consulted the public through exhibitions and sharing information on its planning schemes via the press. Its booming post-war industries, led by a successful conversion to car manufacturing from wartime armaments production, countered arguments about the cost. Rapid and comprehensive redevelopment of the city centre was assumed to be necessary by the local authority from the start. The centrepiece would be the construction of a shopping precinct over the remains of the destroyed Smithford Street, aligning with a new public square at Broadgate, in the medieval core.

Since the 1920s, there had been a division in Coventry between the traditionalists who were fond of the city's medieval 'black and white' buildings and the newcomers who had little affinity with the old city. The voices of the traditionalists had been overwhelmed even before the war, when the Butcher Row area was destroyed in 1936. But in Coventry, no local historical, archaeological group or 'champion' emerged to act as a focal point for opposition to the local authority's plans and its potential effect on the medieval historic fabric of the city. Later, the Coventry Evening Telegraph, reviewing the changes of the previous decade, commented on the loss of the city's historic landmarks and added: 'the sighs of such historians as we still have within the city are so faint that they are not heard'. ${ }^{57}$ Shelton displayed his pre-war medieval archaeological finds in his own make-shift museum, and his efforts were rewarded by the city council which awarded him the honorary title of 'city chamberlain'. But there is no record of plans to investigate the bomb-damaged centre archaeologically before redevelopment in the six or seven years before buildings started to emerge in the 1950s..$^{58}$

The local civic society, the 'Coventry Guild', took the then conventional stance regarding historic buildings that the best of them should be retained where possible, and with 'improved settings'. The Guild had started as an antiquarian society in 1914 but had widened its scope to encompass wider civic concerns, including town planning when it re-launched in $1936 .{ }^{59}$ However, it felt that protecting the city's surviving medieval buildings should not act as a brake on the overall city development plan. There was a feeling that even the best of medieval buildings would have a stay of execution for a matter of 20 years or so before being lost forever. After the war, the Guild was heavily influenced by local authority figures and its president was the Le Corbusier-influenced mayor, who was a

56 Hasegowa, Replanning the Blitzed City, 28, 40; Stamp, Britain's Lost Cities, 52.

57 Coventry Evening Telegraph, Nov. 1955.

58 M. Rylatt, City of Coventry Archaeology and Redevelopment (Coventry, 1977), 9.

59 Coventry Record Office (CRO), PA313/43: Coventry Guild Aims; Richardson TwentiethCentury Coventry, 281; J. Field, Mary Dormer Harris. The Life and Works of a Warwickshire Historian (Studley, 2002), 58, 97. 
keen advocate for Gibson's comprehensive redevelopment plans and who was not in favour of retaining medieval buildings. An important Guild member was Ernest Ford (1884-1955), city engineer from 1924 to 1946 and who had been responsible for the Butcher Row area destructions. ${ }^{60}$ His vision of post-war Coventry was one of widened streets lined with 'Mock Tudor' buildings rather than the large-scale redevelopment proposed by Gibson. While as many of the city's medieval buildings should be retained for as long as possible, 'motor minded Coventry was incompatible with its narrow medieval streets'. ${ }^{61}$ But Ford's rival plan had been decisively rejected by the city council in 1941. Another influential Guild member was Frederick Smith, who as town clerk during the war had the responsibility for leading the city's application for the compulsory purchase of bombdamaged land. He was not a supporter of Gibson's radical approach either and he had effectively tried to slow down progress while in office. ${ }^{62}$ Smith had also been a member of the committee set up by the Association of Municipal Corporations (which consisted mainly of town clerks of blitzed towns) and which was in close contact with the government regarding the preparation of the 1944 Town and Country Planning Bill. Smith had a deep interest in the city's history and in fact was commissioned by the Corporation to write a book, published in 1945, marking the six hundredth anniversary of the city's incorporation. Yet he too felt that saving all of the city's medieval buildings was not a realistic aim. ${ }^{63}$

The Guild continued its support for the city council's reconstruction scheme after the war, but in 1946 set up an 'Antiquities Committee' of eight members to focus on putting together Coventry's list of buildings of historical significance in preparation for the 1947 Act. The committee included Ford and Smith as well as the city librarian, archaeologist J.B. Shelton and the former city archivist (1938-45) and emeritus director of the Shakespeare Birthplace Trust Levi Fox. They were joined by Helen Rotherham of the local watch-making family plus architect Alfred Gardner, who was appointed secretary. Unlike the FOSS, this was not an independent body, and its focus was on informing the local authority rather than engaging the public. The new committee was kept busy until it wound up in 1951 on a number of issues including the examination of rival designs for the rebuild of the destroyed cathedral and, later, submissions for the competition for a brand new cathedral. ${ }^{64}$ Ford was also chair of the cathedral reconstruction committee between 1949 and $1955 .{ }^{65}$

${ }^{60}$ P. Bolton (ed.), The Destroyed Buildings of Warwickshire, Mid-Warwickshire Branch of the Historical Association, 2nd edn ([Birmingham], 1976).

61 Midland Daily Telegraph, 27 Feb. 1941; Ernest Ford, The Reconstruction of a Bomb-Damaged City, in CRO, PA/3/214.

62 Hasegowa, Replanning the Blitzed City, 39, 44, 129.

63 F. Smith, Coventry: Six Hundred Years of Municipal Life (Coventry, 1945); Coventry Evening Telegraph, 25 and 26 Jun. 1946.

${ }^{64}$ CRO, PA313/342.

65 Campbell, 'Towards a new cathedral', 211, 223. 
Agreement on what should be included in the Coventry list was, unlike Southampton, far from smooth. Between 1946 and 1947, the committee put together at least three provisional lists, ending with a 'classified list' of 100 buildings, having first consulted the Ministry. An examination of the draft lists reveals a number of changes. ${ }^{66}$ Most of the proposed listed buildings reflected the city's late medieval heyday. Grades I to IV were used, but only four domestic timber-framed buildings and five undercrofts made the statutory Grades I and II, while 21 domestic buildings were included at Grades III and IV. The vast majority of the city's surviving medieval vernacular buildings failed to be listed at all.

The city council stalled for time regarding acceptance of the final list and replied to the committee that it would appoint a further sub-committee to meet in January 1948 to examine the proposed list in greater detail, and with Gardner invited as a consultant. By this time, the Coventry submission was overdue and the Ministry wrote to the Guild chasing it. ${ }^{67}$ Further debates meant that the list was not finalized until as late as $1955 .{ }^{68}$ Evidently, the city council felt that even listed buildings should not get in the way of its reconstruction plans. ${ }^{69}$ Money was not to be diverted from the reconstruction plan to be spent on restoring medieval buildings, many of which were left to crumble, such as the chapel of St James and St Christopher. Only a few medieval buildings were restored with local authority funds, including the roof of the late medieval St Mary's Guildhall. Later, a city council report admitted how little money had been spent since the war. ${ }^{70}$

Tensions between the committee and the council emerged over the fate of a number of listed buildings between 1948 and 1955. Gardner was forced to appeal to the public via the press to draw attention to the threats, and also to alert the Ministry, national societies, local politicians and industrialists. Gardner wrote to SPAB in August 1948 with details of 'buildings that may face an uncertain future', including the fourteenth-century stone-built scheduled ancient monument, the chapel of the Hospital of St John (also known as the 'Old Grammar School') which was 'not well cared for'. In August 1952, the city council's plans to demolish the building were published in the Coventry Evening Telegraph. ${ }^{71}$ Gardner appealed to the inspector of ancient monuments. ${ }^{72}$ The building

66 CRO, PA313/210/1 and 313/206/4.

67 Ministry to Gardner, 19 Apr. 1947, CRO, PA33/287; C. Barrett, town clerk, to Gardner, 13 Jan. 1948, CRO, PA313/216/2.

68 J. Gould and C. Gould, Coventry: The Making of a Modern City 1939-1973 (Swindon, 2016), 75-6.

69 CRO, PA313/210/1 and PA313/206/4; Gould and Gould, Coventry: The Making of a Modern City, 76 .

$70 \mathrm{CRO}, \mathrm{A}$. Ling, city architecture and planning officer, report to the Coventry City Council Planning and Redevelopment Committee, DPR no. 26, 29 Nov. 1962.

71 Gardner to secretary SPAB, 16 Aug. 1946, SPAB archive Coventry; Coventry Evening Telegraph, 21 Aug. 1952.

72 Gardner to chief inspector of ancient monuments, CRO, PA313-349/3-4. 


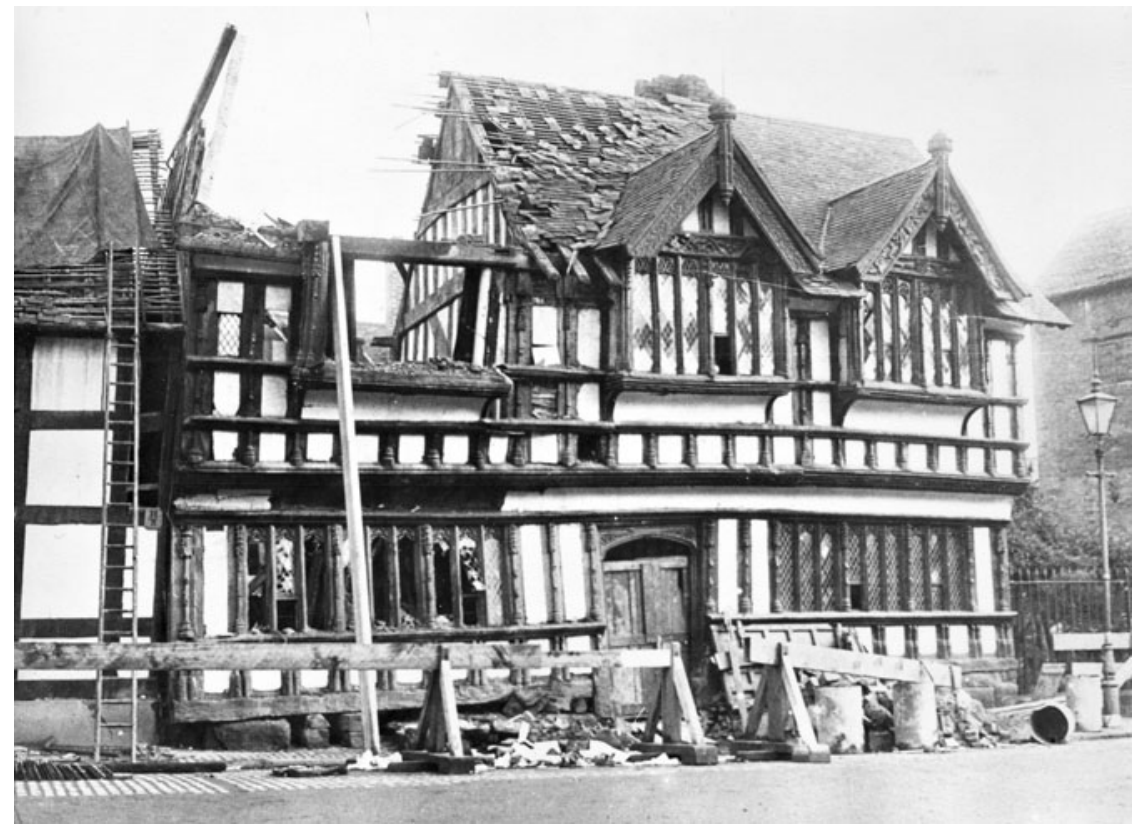

Figure 3: Bomb-damaged Ford's Hospital and adjoining listed building. David MacGrory, with permission.

was given a temporary reprieve, but the battle to save it continued throughout the 1950s.

Another building the committee brought to the attention of SPAB in 1948 was the Grade I Ford's Hospital, built and enlarged between 1511 and 1529, where delays in repairs after bomb damage were resulting in further deterioration (see Figure 3). Ford's Hospital and adjoining (undamaged) Grade I listed medieval timber-framed building at number 27-8 Greyfriars Lane were actually in the path of a proposed new road that Gibson wanted to construct, connecting the city centre from the railway station to the south. Gardner helped launch an appeal to save Ford's Hospital in the press, including in the Birmingham Post, ${ }^{73}$ and eventually the proposed new road was shelved. The building was later repaired through private money, together with a contribution from the War Damage Commission. The building was finally reopened in 1953 but only after the townscape context had been lost when the adjoining building at number 27-8 was demolished, despite its Grade I listed status.

By 1952, attention had shifted to the surviving parts of Cheylesmore Manor House, former residence of the earls of Chester and princes of Wales since the twelfth century and a Grade I scheduled ancient monument.

${ }^{73}$ Gardner letters to various newspapers, CRO, PA 313/277/9. 
After protests, an estimate of $£ 12$ million was proposed for its repair under a restoration plan by Gardner but no one was able to come up with the funds. The oldest section, the east wing, was taken down in $1956 .{ }^{74}$ The surviving sixteenth-century gatehouse was later restored and became the city registrar's marriage rooms. Also in 1952, there was a debate about the fate of fragments of the medieval town wall, another scheduled ancient monument. Bryan O'Neill (1905-54), medieval archaeologist and the chief inspector of the ancient monuments branch of the Ministry, inspected the walls and disagreed with the case for demolition. In a strongly worded internal memo in December 1952, he criticized the city council's attitude. ${ }^{75}$ In the end, the city council was forced to back down and the affected sections of the wall were saved.

Was there opposition from the public to the loss of medieval buildings? Most accounts of the period point to a consensus between the local authority and the public about the need to remodel the city centre. ${ }^{76}$ This opinion is partly based on the huge turnout at the Coventry of the Future exhibition of October 1945 when up to 57,500 people (a quarter of the population) attended over two weeks. ${ }^{77}$ The exhibition at Exeter is another example of a town plan in a former medieval town that was put to the public and attended by a substantial proportion of the population. ${ }^{78}$ But was attending an exhibition necessarily an endorsement of what the visitors saw? Examples of panel photographs from the Coventry exhibition reveal a polemical tone (see Figure 4). The exhibition brochure refers to the medieval town as an 'incoherent, unplanned mess ${ }^{\prime 79}$ and as a mistake that ought never be repeated. Leading comparisons were made between the old and the new, and interspersed with enticing pictures of new 'mod cons'. The larger buildings like Holy Trinity and the surviving tower and spire of St Michael's were to be retained and even emphasized through grand vistas from the new shopping precinct and the realigned Broadgate area. But the references to vernacular buildings and medieval streets were dismissive. The proposals were sketchy and deliberately made to look less alarming. ${ }^{80}$ In particular, there was no detail about what would happen to vernacular buildings that stood in the way of areas earmarked

74 T. Gregory, 'Coventry', in J. Holliday (ed.), City Centre Redevelopment: A Study of British City Centre Planning and Case Studies of Five English City Centres (London, 1973), 83.

75 Larkham, Continual Change, 15.

${ }^{76}$ Hasegowa, Replanning the Blitzed City, 90; cf. D. Kynaston, Austerity Britain 1945-51 (London, 2007), 166-7.

77 Larkham and Lilley, 'Exhibiting the city', 660.

78 Ibid., 660-1.

79 The Future of Coventry: Some Proposals and Suggestions for the Physical Reconstruction and Planning of the City of Coventry, Corporation of Coventry, 1945, 24-5, CRO. Modernist planners were not necessarily correct in their assessment of the unplanned nature of medieval towns; see K.D. Lilley, 'Modern visions of the medieval city: competing conceptions of urbanism in European civic design', Environment and Planning B: Planning and Design, 26 (1999), 427-46.

${ }^{80}$ Campbell, 'Paper dream city', 127-9. 


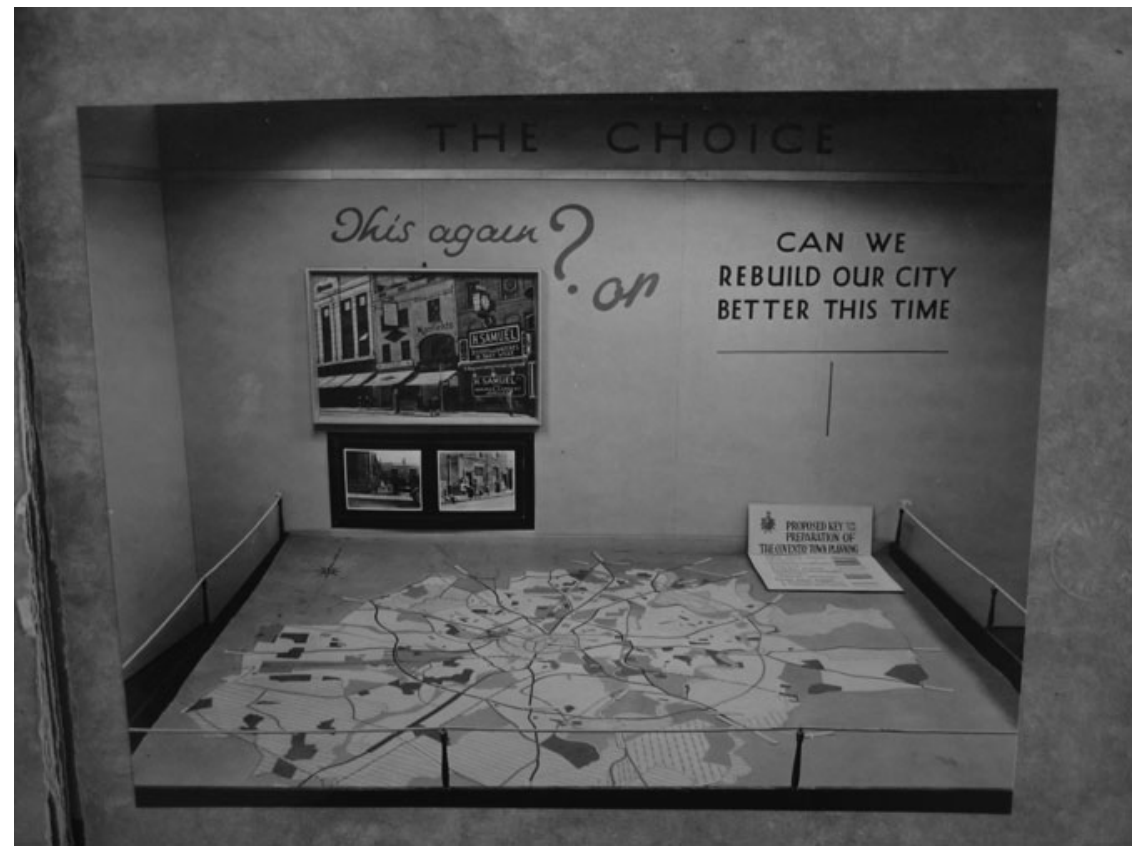

Figure 4: Photograph from the 1945 Coventry of the Future exhibition. $\mathrm{CRO}$, with permission.

for redevelopment other that a vague reference to a 'garden of rest' or 'museum of medieval city development' in Spon Street. ${ }^{81}$

There were in fact several individual objections to the new vision for Coventry, including letters to the local press following the exhibition. One of these was by Herbert Edwards who, on behalf of his group who had attended the exhibition, lamented the loss of the buildings of old Coventry, and reflected that 'the rigid lines of monotonous buildings' would 'utterly spoil' the city centre and would be 'foreign' to the traditional setting. ${ }^{82}$ There may have been other letters received but not published by a proredevelopment press. Further public opposition to the Coventry central area reconstruction plans emerged in January 1946, during the public enquiry on the Declaratory Order under the 1944 Act allowing authorities to apply for compulsory purchase powers and develop bomb-damaged land roughly covering the extent of the intra-mural medieval city. Of the 259 objections, there were five from heritage bodies who referred to the destruction of the medieval street pattern and to historic buildings and

81 The Future of Coventry, 41.

82 Coventry Evening Telegraph, 10 Oct. 1945. 
their traditional setting. There were also seven objections from churches and places of worship. ${ }^{83}$

At least one alternative scheme that took greater account of Coventry's heritage was put forward. Thomas Lloyd Humberstone produced a booklet as an alternative vision to that of the 1945 Corporation's City of the Future brochure. He rejected the radical nature of the plan on offer and asked 'why attempt to out Goering Goering?'. He questioned why the council deemed so much of the city's housing stock as obsolete and decried the threats to the city's antique buildings, despite the theoretical protection given to them under the 1947 Act. He remarked that the city councils' proposals in Coventry were 'alien to its history and character'. His solution envisaged underground roads, pedestrian subways, protection for the city's historic buildings and investment on education for schoolchildren on the city's history. ${ }^{84}$ Humberstone found a kindred spirit in architect Giles Gilbert Scott (1880-1960), whose design for rebuilding St Michael's cathedral in the gothic style had been unexpectedly rejected by the Fine Arts Council. Scott wrote to Humberstone saying he preferred a gradual evolution in architecture rather than 'sudden revolution' and that the modern style is 'entirely throwing over the past' ${ }^{85}$ But Humberstone's alternative plan did not find favour with the city council and was not even discussed in committee.

Unease about the loss of Coventry's medieval character is also apparent from the, admittedly limited, oral history evidence conducted in 2002 of a sample of people who lived through the changes. No doubt much of the evidence was offered with the benefit of hindsight. Some design flaws of Gibson's shopping precinct became apparent only in the late 1950s and $1960 s^{86}$ and some of the criticisms were perhaps coloured by the later 'second wave' of modernist, concrete and high-rise redevelopment that occurred in the 1960s under Gibson's successor Arthur Ling, including the inner ring road. Yet many of the oral history accounts refer with nostalgia to the 'black and white' buildings of the pre-war city. The 20 years of reconstruction was also a disorientating experience for Coventrians in which the full impact of the loss of major features of the town they knew, like Smithford Street, occurred only when the new precinct was emerging, around $1953 .{ }^{87}$

Amongst those who were saddened by the loss of well-loved medieval landmarks and streets, there may have been a sense of helplessness and that the opposing forces were too powerful to resist. During the

${ }^{83}$ Richardson, Twentieth-Century Coventry, 292.

84 T.L. Humberstone, Coventry of the Future, 15 Gower St London (1947), CRO, $\mathrm{PA} 3 / 3 / 214 / 3.4$.

85 G. Scott to T.L. Humberstone, 13 Jan. 1947, CRO, PA3/3/214/3.5.

${ }^{86}$ Hubbard, Faire and Lilley, 'Contesting the modern city'; P. Hubbard and K.D. Lilley, 'Pacemaking the modern city: the urban politics of speed and slowness', Environment and Planning D: Society and Space, 22 (2004), 273-94

${ }^{87}$ Lilley, 'Conceptions and perceptions'. 
period 1945-55, the power of the local authority in Coventry, backed by the press, combined with a lack of an independent heritage protection body, contributed to the sense of having to bow to the inevitable. Such helplessness in the face of stronger forces for change was felt in other towns. ${ }^{88}$ At the time of the 1945 exhibition, ordinary people were far more interested in getting back to normal after the war, and town plans were seen as too technical and remote from daily living. ${ }^{89}$ Often, it was when the new plans became a reality in the mid-1950s that the full impact of townscape changes became apparent.

\section{Conclusion}

It has become something of a cliché to state that post-war planners did more damage to Britain's historic towns than the Luftwaffe. During the war, there was undoubtedly a rather hasty clearing away of bombdamaged medieval building stock, much of it by untrained demolition squads. ${ }^{90}$ There was also a feeling that leaving ruined buildings on show was bad for morale. But the destruction of medieval fabric continued after hostilities had finished, especially in bomb-damaged cities like Bristol and Coventry. Interestingly, nowhere in British towns was there a clamour for wholesale building of 'replicas' of streets lost through wartime bombing, even in smaller towns with an extensive medieval character like Exeter. Planner Thomas Sharp (1901-78) felt that a rebuilding of Exeter on medieval lines would have created a 'dead museum'. ${ }^{91}$ The need to reassert cultural values as seen in the complete rebuilding of pre-war medieval Warsaw and in towns in Germany and the Netherlands ${ }^{92}$ was not felt in Britain.

Much of the reason for the loss of medieval character in British towns must be assigned to the evolving nature of urban conservation itself. The received wisdom amongst heritage experts was that a balance should be struck between the needs of reconstruction and saving old buildings. Summerson declined to support the campaign to save Ford's Hospital in 1949, commenting that that 'we cannot, surely perpetuate an obsolete town-plan for the sake of one ancient and rather beautiful building.${ }^{93}$ Even where medieval buildings could be saved, the concept of preserving the best examples of them in 'improved settings' meant that the 'townscape'

88 Godfrey, Our Building Inheritance, 46; Lilley 'Conceptions and perceptions', 154.

89 Kynaston, Austerity Britain, 49-50; Beach and Tiratsoo, 'The planners and the public', 5435.

90 SPAB secretary to J. O'Neil, the Ministry of Works and Buildings, 23 Dec. 1940, SPAB archive Coventry; S. Glendenning to McGregor, SPAB, 30 Jun. 1943, SPAB archive Coventry.

${ }^{91}$ Matless, Landscape and Englishness, 209-10.

92 S. Jankowski, 'Warsaw: destruction, secret town planning 1939-44 and postwar reconstruction', in J.M. Diefendorf (ed.), Rebuilding Europe's Bombed Cities (London, 1990), 77-93.

93 Summerson, 'The past in the future', 231-2. 
significance was often lost. It is also overlooked that in many towns in the period 1945-55, efforts to save medieval buildings were assumed only to be a temporary measure and that eventual destruction was inevitable. ${ }^{94}$

The failure to allocate enough resources under the 1947 Act statutorily to list and protect all medieval buildings meant that once the real reconstruction work got underway in the 1950s and 1960s, hundreds of medieval vernacular buildings were destroyed without record. But as the evidence from this article shows, even Grade I and II listed buildings were not safe if a local authority was determined enough to enforce its rebuilding programme. The failure to conduct medieval archaeological excavations in British towns between 1945 and prior to actual building work in the 1950s was a missed opportunity. Below-ground archaeology remained entirely unprotected by law for more than 40 years after 1947 and the rate of destruction of medieval archaeology and standing buildings in the 1950s and 1960s led to the CBA setting up an Urban Research Committee in 1968. Its report in 1972 came to the alarming conclusion that at then rates of destruction, there would be no more archaeology left in historic British towns in 20 years' time..$^{95}$

Decisions on which historic buildings to keep and which to remove under the 1947 Act, as well as protecting the listed buildings once agreed, were largely left to local efforts. This is why a detailed study of local decision-making in the period 1945-55 is important to the understanding of the medieval appearance of large British towns and cities today. The destruction of surviving medieval character was not inevitable. Thomas Sharp was an early advocate for 'townscapes', and in his planning for Durham, Exeter, Salisbury, Oxford and Chichester, he eventually saw narrow medieval streets and groups of ordinary buildings as assets. ${ }^{96}$ Other town planners who took a radical approach in large cities took a different approach elsewhere, such as Adshead, when he moved on to medieval York from Southampton. Larkham feels that the main difference between the approach taken in plans in industrial as opposed to 'historic' towns was not the extent of bomb-damage but whether they were in 1945 still recognizably 'medieval' or 'Georgian'. 97

In Southampton, an independent heritage 'watchdog' was set up under a charismatic and respected champion and which was adept at engaging the local public via the press to ward off threats to medieval buildings, and even to begin archaeological excavations. There were other examples. The Citizens Defence Association, which won all seats in the 1945 local

94 E.g. Gardner to Humberstone, 25 Apr. 1947, CRO, PA3/3/214.

95 C. Heighwey (ed.), The Erosion of History: Archaeology and Planning in Towns (CBA Urban Research Committee, 1972); Biddle and Hudson The Future of London's Past; J. Summerson, 'Introduction', in 50 Years of the National Buildings Record 1941-1991 (Royal Commission on the Historical Monuments of England, 1991).

96 Pendlebury, 'Planning the historic city', 385-91.

97 P.J. Larkham, 'The place of urban conservation in the UK reconstruction plans of 1942-52', Planning Perspectives, 18 (2003), 316. 
elections in Canterbury, was an example of heritage protectionists and others joining forces successfully to overturn the most destructive aspects of a redevelopment plan in a medieval city. The Norwich Society had opposed Norwich city council's repeated attempts to reorder the medieval city since it formed in 1923, and with mixed results, as did the Council for the Protection of Ancient Bristol with regard to its local authority after the war. The Old Edinburgh Club, formed in 1908, had long been a powerful preservation voice. In Coventry, no group emerged to take on such a role, and threats to medieval buildings were the preoccupation of a sub-committee of a local authority-dominated civic society that was broadly in favour of the city council's reconstruction plans. After 1958, no medieval buildings were destroyed in Southampton, yet in Coventry that year was the start of a new wave of redevelopment that destroyed even more medieval buildings than in the previous decade. Up to 100 medieval buildings were taken down in Coventry between 1945 and 1970.98

A detailed examination of local decisions made between 1945 and 1955, as evidenced by local and national archives, reveals that the balance between local authority enthusiasm for radical redevelopment and the level of public support for retaining key historic buildings and streets could result in different outcomes that affected the medieval character of large British towns. It also demonstrates the extent to which different towns were prepared to use medieval archaeology and standing buildings as a 'sense of place' in their reconstruction schemes. The influence of what we might now term a local heritage 'champion' or group could make the difference at a time when the national protection structure was limited. It was not until the introduction of 'conservation areas' in the Civic Amenities Act of 1967 that a 'townscape' approach to the preservation of historic character, often medieval, offered a measure of adequate protection. While most post-war destruction of urban medieval character took place in the 1950s and 1960s, this was largely as a result of decisions made in the immediate post-war decade.

98 Jones, 'Timber-framed buildings in Coventry'; M. Rylatt, 1981, Woodfield papers and pers. comm. 